\title{
Volatile Composition and Sensory Properties as Quality Attributes of Fresh and Dried Hemp Flowers (Cannabis sativa L.)
}

\author{
Andrzej Kwaśnica ${ }^{1,2, *}{ }^{\circ}$, Natalia Pachura ${ }^{1, *}$, Klaudia Masztalerz ${ }^{3}{ }^{\oplus}$, Adam Figiel $^{3}{ }^{\circ}$, \\ Aleksandra Zimmer ${ }^{3}{ }^{\circledR}$, Robert Kupczyński ${ }^{4}{ }^{\circledR}$, Katarzyna Wujcikowska ${ }^{4}$, \\ Angel A. Carbonell-Barrachina $\left.{ }^{5}{ }^{(}\right)$, Antoni Szumny ${ }^{1}{ }^{\mathbb{D}}$ and Henryk Różański ${ }^{6}$
}

1 Faculty of Biotechnology and Food Science, Wrocław University of Environmental and Life Sciences, Norwida 25, 50-375 Wrocław, Poland; antoni.szumny@upwr.edu.pl

2 Laboratorium Badań Toksykologicznych Lab4Tox Sp. z o.o., ul. Kruszwicka 24/66, 53-652 Wrocław, Poland

3 Institute of Agricultural Engineering, Wrocław University of Environmental and Life Sciences, Chełmońskiego 37-41, 51-630 Wrocław, Poland; klaudia.masztalerz@upwr.edu.pl (K.M.); adam.figiel@upwr.edu.pl (A.F.); zimmer.ola@gmail.com (A.Z.)

4 Department of Environment, Animal Hygiene and Welfare, Wrocław University of Environmental and Life Sciences, Chełmońskiego 38C, 51-630 Wrocław, Poland; robert.kupczynski@upwr.edu.pl (R.K.); k.wujcikowska@gmail.com (K.W.)

5 Departamento Tecnología Agroalimentaria, Universidad Miguel Hernández, Carretera de Beniel, 03312-Orihuela, Alicante, Spain; angel.carbonell@umh.es

6 Institute of Health and Economy, Carpathian State College in Krosno, Rynek 1, 38-400 Krosno, Poland; rozanski@rozanski.ch

* Correspondence: andrzej.kwasnica@upwr.edu.pl (A.K.); natalia.pachura@upwr.edu.pl (N.P.)

Received: 21 June 2020; Accepted: 10 August 2020; Published: 13 August 2020

\begin{abstract}
Flowers of hemp (Cannabis sativa L.) are widely used in cosmetics, food, and in the pharmaceutical industry. The drying process plays a key role in retention of aroma and also in the quality of products. Seven variants of hemp flower drying, including convection drying (CD), vacuum-microwave drying (VMD), and combined drying consisting of convective pre-drying followed by vacuum-microwave finishing drying (CPD-VMFD) were checked in this study. For each process, we applied the two-term model. Dried material was submitted to color and chromatographical assessments. Analyses of obtained essential oil showed the presence of 93 volatile compounds, predominantly $\beta$-myrcene, limonene, and $\beta$-(E)-caryophyllene, as well as $\alpha$-humulene. Application of $240 \mathrm{~W}$ during VMD and $50{ }^{\circ} \mathrm{C}$ during $\mathrm{CD}$ gave the highest retention of aroma compounds, amounting to 85 and $76 \%$, respectively, but with huge color changes. Additionally, sensory analysis proved that drying with a microwave power of $240 \mathrm{~W}$ provides a product most similar to fresh material.
\end{abstract}

Keywords: Cannabis sativa L.; drying methods; essential oils; sensory evaluation

\section{Introduction}

Cannabis sativa $\mathrm{L}$. is an annual herbal plant of the cannabis species (Cannabaceae) that has been known and cultivated especially in Asia since ancient times [1]. Nowadays, it is already cultivated all over the world and has a wide range of applications, including food, dietary supplements, medicines, body care products, fuel, paper, and as a building material, as well as a role in textiles [2]. Hemp contains around 750 natural chemical compounds, which can be classified into different classes [3]. The abundance of chemicals in cannabis flowers stems from the biosynthesis, particularly of terpenes and cannabinoids in the extracellular secretory cavity, known as the trichome. The active substances are secreted into 
the trichomes to prevent damage to plant cells and are the first line of defense against the external environment [4].

The most common and basic technique for conserving herbs and retaining bioactive compounds is drying. The research shows that, depending on the choice of drying method and parameters, different chemical and biological activity of herbs is obtained, due to different content of chemical compounds in their composition [5]. The selection of the drying method has a major influence on the content of volatile essential oils present in herbs, as shown in earlier studies [6-10]. During the drying process, the following changes in the composition of the essential oil may occur-an increase or decrease in the concentration of volatile substances, or the formation of new chemical compounds [5]. The most commonly used drying method is convection drying (CD), a process using a continuous flow of hot air to remove moisture from the biological material [11]. With the development of technology, alternatives for better drying performance have emerged, such as vacuum-microwave drying (VMD) and combined methods consisting of convectional pre-drying followed by vacuum-microwave finishing drying (CPD-VMFD). The VMD method allows faster drying of the material while avoiding high temperatures [12]. Due to the high cost of production, an alternative drying method, CPD-VMFD, has been proposed due to the requirement of high vacuum during drying. This multi-stage drying process coupling the two CD and VMD methods together allows a satisfactory degree of drying of the material as it offers the advantages of the VMD method with the high performance that the CD method provides [11].

Recently, there has been a focus on the use of secondary metabolites from hemp flowers, which are characterized by low tetrahydrocannabinol (THC) content, which are known as nonpsychotropic cannabinoids, terpenoids, and flavonoids [13-15]. Essential oils extracted from hemp flowers are widely used in cosmetology as ingredients used in the production of creams, soaps, and shampoos, as well as in the food industry as aromas for alcoholic and non-alcoholic beverages and additives in baking [16]. Hemp essential oils have shown an interesting antimicrobial effect and can constitute an economic, effective antiseptic. They are therefore used to treat wounds and infections such as food poisoning and nosocomial infections, and can be used against antibiotic-resistant bacterial strains [17]. In addition, they are commonly used as insecticides [18,19], fungicides [20], and growth inhibitors for unwanted plants [21], and can be used in plant protection as a means of stopping plant diseases and pest attacks [19]. Cannabinoids contained in hemp also play a special role. They are responsible for the modulation of hunger/satiety and participate in peripheral metabolic reactions of the liver, fat, muscles, and anti-inflammatory reactions in blood cells [22]. Despite this, they can also cause side effects such as imbalance, hallucinations, nausea, and drowsiness [23].

Hemp can also be used as a source of food because of its health-promoting properties. Hemp seed oil is characterized by high levels of exogenous fatty acids (EFA) and polyunsaturated fatty acids (PUFA) [24]. The oil contains linoleic acid and L-linolenic acid, as omega- 6 and omega-3 acids, which are optimal for nutrition because of their proportions (3:1, LA:LNA). Hemp seed oil is additionally enriched with gamma-linolenic acid (GLA), which makes the nutritional value ultimately higher than most seed oils. A properly balanced oil prevents excessive accumulation of certain metabolic products and also provides the necessary intermediaries for the body to work efficiently. The benefits of hemp seed oil as a food product and food supplement are that it can enrich the diet of the potential consumer [25].

The leading theme of the research was to define the composition of the volatile profile of hemp flowers and to verify how selected drying methods influence the profile of volatile compounds and the contribution of cannabinoids. For this purpose, we distilled the essential oil from the material under study and then analyzed it using gas chromatography in combination with the mass spectrometry technique (GC-MS). 


\section{Materials and Methods}

\subsection{Plant Material}

Approximately $20 \mathrm{~kg}$ of hemp flowers var. Henola were harvested on 15 October 2019 from commercial field in Oborniki Ślasskie $\left(16^{\circ} 55^{\prime} \mathrm{E}, 51^{\circ} 18^{\prime} \mathrm{N}\right)$ Poland. The whole flowers, after being manually detached from the stem, were mixed and immediately subjected to drying, the distillation processes, as well as subsequent chemical analyses. The initial moisture content of the material was $68 \%$ wb (wet basis), assessed by a vacuum dryer SPT-200 ZEAMIL (Horyzont, Krakow, Poland). Plant material was subjected to various drying processes, which were suspended when no changes in weight were observed. The voucher specimen of investigated flowers were deposited in local herbarium at the Department of Chemistry.

\subsection{Drying Methods}

In the study, three different drying methods were applied: convective drying (CD), vacuum-microwave drying (VMD), and combined drying consisting of convective pre-drying and vacuum-microwave finishing drying (CPD-VMFD). Approximately $60 \mathrm{~g}$ of hemp flowers were used in each case, and the process was carried out until the final moisture content of the sample was below $10 \%$ wb. This initial loading mass of sample allowed for thin layer drying without of the raw material compacting, which was necessary to meet the requirements for modeling the drying kinetics and to provide a sufficient amount of dry material for quality tests.

\subsubsection{Convective Drying (CD)}

The CD was conducted on an apparatus located at the Institute of Agricultural Engineering (Wrocław University of Environmental and Life Sciences, Wrocław, Poland). The hemp flowers were placed in a special container $(\mathrm{d}=100 \mathrm{~mm})$ and dried in $50{ }^{\circ} \mathrm{C}, 60^{\circ} \mathrm{C}$, and $70{ }^{\circ} \mathrm{C}$ with an airflow of $0.5 \mathrm{~ms}^{-1}$. The preliminary tests revealed that that drying at temperatures below $50{ }^{\circ} \mathrm{C}$ takes too long to be applicable in industrial conditions in terms of energy consumption and thus operating costs, while temperatures above $70{ }^{\circ} \mathrm{C}$ lead to a drastic degradation of the chemical composition of the dried product. Due to difficulties in low temperature drying of hemp flowers, the temperatures used in this study were slightly elevated compared to the temperatures used for drying of some other herbal products such as thyme [6], sweet basil [8], or marjoram [7].

\subsubsection{Vacuum-Microwave Drying (VMD)}

The VMD was performed using the SM 200 dryer (Plazmatronika, Wrocław, Poland). The samples were placed in a glass cylindrical drum that rotated at $6 \mathrm{rpm}$. The dryer was equipped with a BL 30P vacuum pump (Tepro, Koszalin, Poland), MP 211 vacuum manometer (Elvac, Bobolice, Poland), and a $0.15 \mathrm{~m}^{3}$ compensation tank. During the drying process, we used three power levels (240, 360, and $480 \mathrm{~W}$ ) and pressure in the range of 4-6 kPa. Microwave powers were selected on the basis of the results from previous studies where similar materials were successfully dried in these conditions [6]. The maximum temperature of the dried hemp flowers was measured after removal from the dryer using an i50 infrared camera (Flir Systems AB, Stockholm, Sweden).

\subsubsection{Combined Drying Consisting of Convective Pre-Drying Followed by Vacuum-Microwave} Finishing Drying (CPD-VMFD)

During combined drying, the samples were initially placed in drying baskets at the convective dryer for $60 \mathrm{~min}$ at $60{ }^{\circ} \mathrm{C}$; then, the samples were moved to a vacuum-microwave dryer where finishing of drying at $360 \mathrm{~W}$ occurred until its final moisture content was below $10 \% \mathrm{wb}$. The time of convective pre-drying was proposed on the basis of preliminary studies, which showed that by that time water was effectively removed from the raw material at a satisfactory drying rate. 


\subsubsection{Modelling of Drying Kinetics}

Drying kinetics of hemp flowers were presented using a moisture ratio $M R$ defined by relationship (1):

$$
M R=\frac{M_{(t)}-M_{e}}{M_{0}-M_{e}}
$$

where $M_{(t)}$ is the moisture content of the sample at given time, $M_{0}$ is the initial moisture content, and $M_{e}$ is an equilibrium moisture content that is usually omitted as the values of $M_{e}$ are relatively small (compared to $M_{(t)}$ and $M_{0}$ ), and therefore the simplified relationship (2) was used in the study without any significant influence on the drying kinetics modeling [26]:

$$
M R=\frac{M_{(t)}}{M_{0}}
$$

On the basis of obtained experimental data, we fitted several empirical drying models, including Newton, Midelli et al., logarithmic, two-term, and Page's models, performed using TableCurve 2D software. The results of preliminary tests revealed that only the two-term equation (Equation (3)) can be considered, as it takes into account the best fit determined according to the highest values of $R^{2}$ and the lowest values of root mean square error (RMSE).

$$
M R=a \cdot e^{-k_{1} \cdot t}+b \cdot e^{-k_{2} \cdot t}
$$

where $k_{1}$ and $k_{2}$, and $a$ and $b$ denote drying constants and model coefficients, respectively.

\subsection{Color Analysis}

Color of the samples was measured in five repetitions using a Minolta Chroma Meter CR-400 (Minolta Co., Ltd., Osaka, Japan). The results were obtained in reference to International Commision on Illumination (CIE) $L^{*} a^{*} b^{*}$ color space, where $L^{*}$ stands for lightness, $a^{*}$ values vary between negative (green) and positive (red), and $b^{*}$ values vary between negative values indicated as blue and positive values indicated as yellow hues. The total change in color of dried material was expressed as $\mathrm{DE}^{*}$ according to the following formula:

$$
\Delta E^{*}=\sqrt{\left(L_{0}^{*}-L^{*}\right)^{2}+\left(a_{0}^{*}-a^{*}\right)^{2}+\left(b_{0}^{*}-b^{*}\right)^{2}}
$$

where $L_{0}{ }^{*}, a_{0}{ }^{*}$, and $b_{0}{ }^{*}$ denote the values of fresh material.

\subsection{Distillation of Essential Oil (EO)}

In the process of extraction of essential oils (EOs), we used the Deryng apparatus. A suitable quantity of weighed fresh or dried material was transferred to a $250 \mathrm{~mL}$ round-bottomed flask. The hemp flowers were poured with $100 \mathrm{~mL}$ of distilled water. The flask was placed in a heating mantel and the mixture was brought to boiling point and kept at this temperature for $45 \mathrm{~min}$. When the boiling point was reached, we added $1 \mathrm{~mL}$ of cyclohexane to collect the essential oil, which contained $1 \mathrm{mg}$ of 2-undecanone as internal standard (Sigma-Aldrich, Saint Louis, MO, USA). After the extraction process, organic phase with the essential oil was collected and stored at $-18^{\circ} \mathrm{C}$ until chromatographical analysis.

\subsection{GC-MS Analyses}

The profile of volatile compounds was analyzed using a gas chromatograph coupled with a mass spectrometer (Shimadzu GCMS QP 2020, Shimadzu, Kyoto, Japan). Separation was obtained by a capillary column Zebron ZB-5 ( $30 \mathrm{~m}, 0.25 \mathrm{~mm}, 0.25 \mu \mathrm{m}$; Phenomenex, Torrance, CA, USA). The GC-MS analysis was carried out according to the following parameters: scanning in the range from 35 to $320 \mathrm{~m} / \mathrm{z}$ in electron ionization mode at $70 \mathrm{eV}$, in the option of $3 \mathrm{scans} \mathrm{s}^{-1}$. Analyses were performed 
using helium as a carrier gas at a flow rate of $1.11 \mathrm{~mL} \mathrm{~min}^{-1}$ in a split ratio of 1:20. The GC oven temperature was programmed from $45^{\circ} \mathrm{C}$ as initial temperature to $150^{\circ} \mathrm{C}$ at a rate of $2{ }^{\circ} \mathrm{C} / \mathrm{min}$, then to $270{ }^{\circ} \mathrm{C}$ at a rate of $15^{\circ} \mathrm{C}$ and kept for $5 \mathrm{~min}$.

Identification of compounds were based on 3 independend methods: (a) comparison of obtained spectra with databases NIST 17 (National Institute of Standards and Technology) [27] and FFNSC (Mass Spectra of Flavors and Fragrances of Natural and Synthetic Compounds) [28], (b) comparison of calculated retention indices (RI) using a retention indices calculator [29] with values presented in NIST 17 and FFNSC, and (c) comparison of retention times of unknown compounds with authentic standards. For comparison of mass spectra, we used the AMDIS (v. 2.73) and GCMS solution (v. 4.20) programs. Additionally, all experimental RI were compared with those published in Adams [30].

\subsection{Sensory Evaluation}

The intensity of the main sensory attributes of dried hemp flowers were evaluated by a trained sensory panel. The panel consisted of 7 panelists (4 males and 3 females), aged between 34 and 53 years old. Panelists belonged to the research group "Food Quality and Safety" of the Universidad Miguel Hernández de Elche (UMH) and had over $1000 \mathrm{~h}$ of evaluation experience. The panel was selected and trained following the International Organization for Standardization ISO standard 8586-1 (1993), and it is specialized in descriptive sensory evaluation of fruits and vegetables and has a wide expertise in studying the effects of drying on different matrixes, such herbs, fruits, vegetables, and mushrooms [31].

Descriptive sensory analysis (DSA) was used to describe the dried hemp flowers. During 1 orientation session of $90 \mathrm{~min}$, panelists discussed about the main odor (perception of volatile compounds with the product outside the mouth) and agreed on their use of key attributes/descriptors. Panelists agreed that the sensory profile of these dried samples could be described using 11 attributes: (i) fresh material: hemp flower ID, fresh vegetables, citrus, balsamic, spicy, and anise odor; and (ii) dried material: cooked, hay-woody, camomile, earthy, and burnt. Reference products of these attributes, with intensity similar to those of the samples under evaluation were prepared and provided to the panel.

The evaluation was performed in normalized individual booths with controlled illumination and temperature, $23 \pm 2{ }^{\circ} \mathrm{C}$. Samples coded with 3-digit random numbers were randomly presented to each panelist in odor-free plastic beakers of $100 \mathrm{~mL}$ with lids; samples were left for $15 \mathrm{~min}$ at room temperature prior to analysis. The 9 samples under analyses were analyzed in 3 sessions in which 3 samples per session were randomly presented to the panel; this design was selected to avoid sensory fatigue. The intensity of the sensory attributes was scored using a scale from 0 to 10 , where $0=$ none or not perceptible intensity and $10=$ extremely high intensity.

\subsection{Statistical Analysis}

All analyses were performed using the STATISTICA 13.3 software (StatSoft, Krakow, Poland). Data are expressed as means values \pm standard deviation. Before analyses, all data were screened for normality using the Shapiro-Wilk test. The results from drying kinetics were subjected to the analysis of variance using Tukey's test $(p<0.05)$ and the results from analyses of essential oils were subjected to the analysis of variance using Duncan's test $(p<0.05)$. The data from the sensory analysis were also subjected to the Honest Significance Difference (HSD) Tukey's test $(p<0.05)$.

\section{Results and Discussion}

\subsection{Drying Methods}

Figure 1 shows the drying kinetics of hemp flowers treated by convective drying (CD) (a), vacuum-microwave drying (VMD) (b), and combined drying (CPD-VMFD) (c), whereas Table 1 presents model constants with drying times and maximum temperature during drying using different methods. 


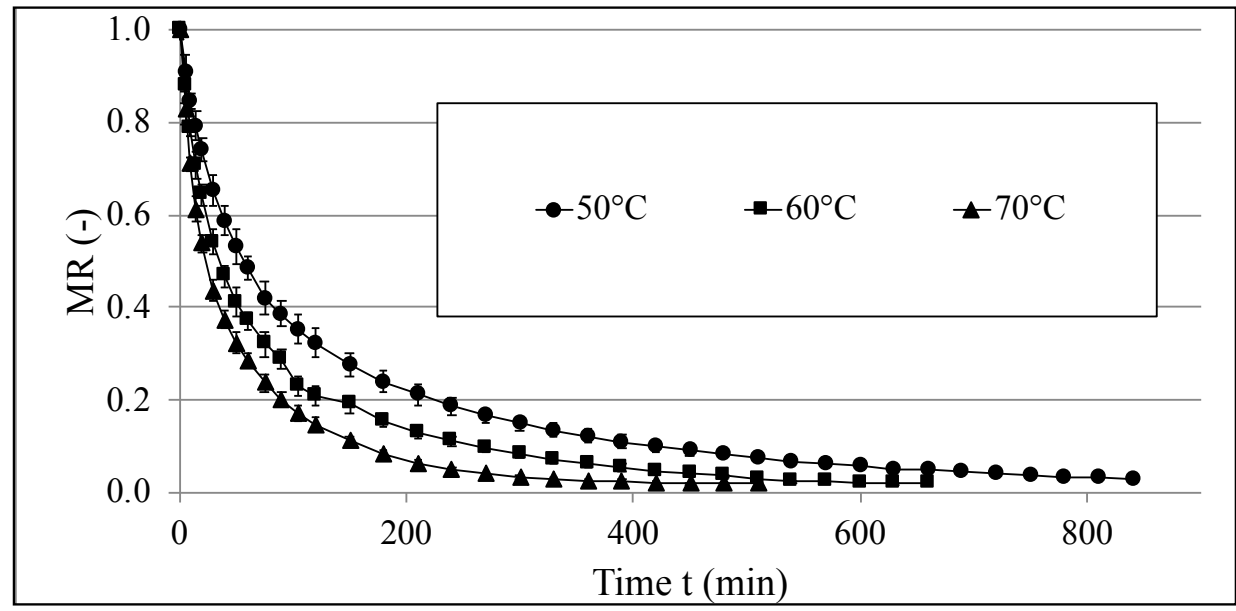

(a)

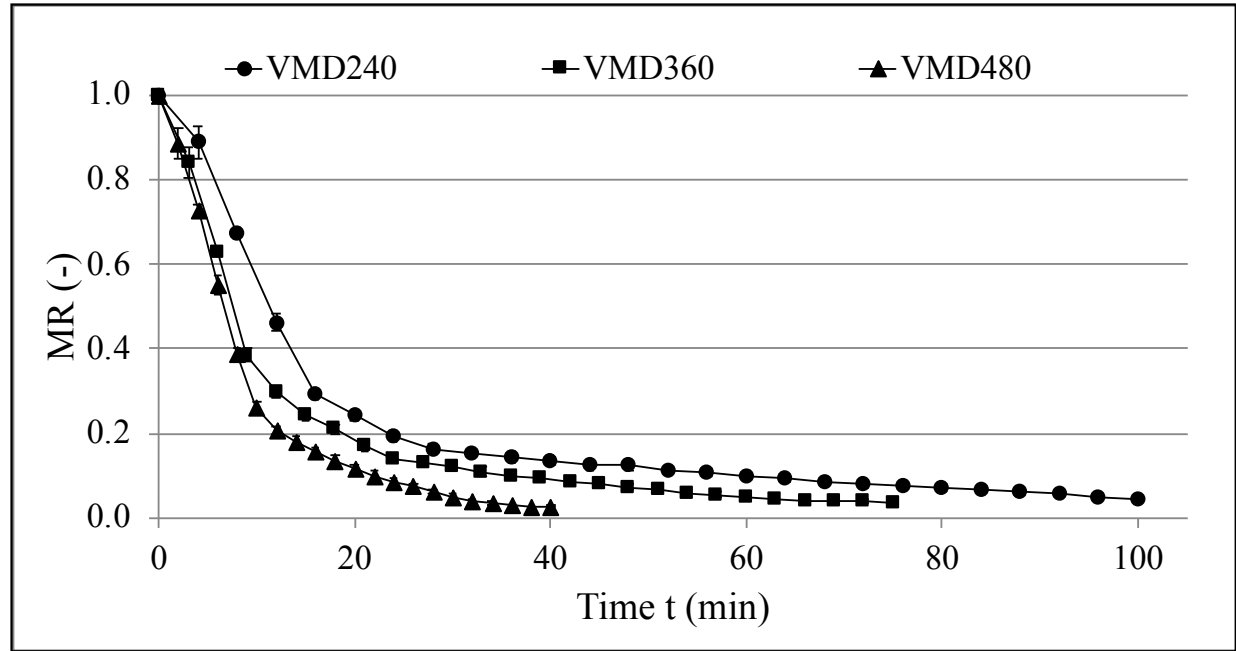

(b)

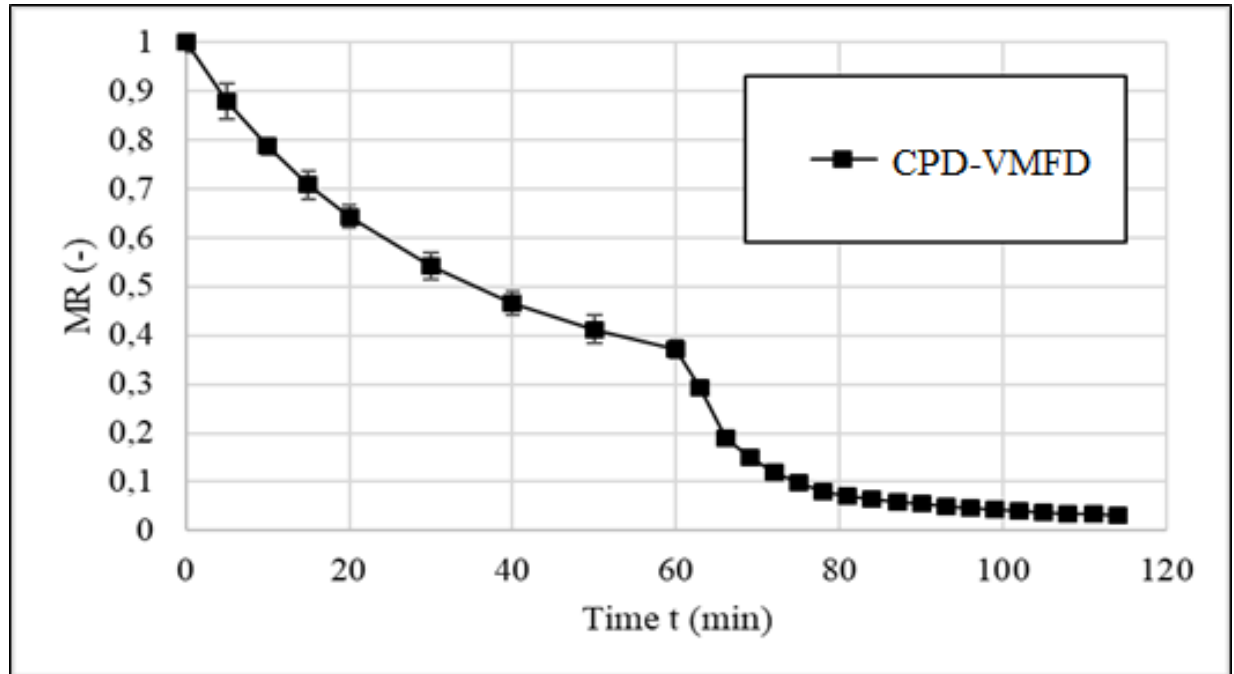

(c)

Figure 1. Drying kinetics of hemp flowers treated by convective drying (CD) at 50,60 , and $70{ }^{\circ} \mathrm{C}$ (a); vacuum-microwave drying (VMD) at 240, 360, and $480 \mathrm{~W}$ (b); and combined drying consisting of convective pre-drying (CPD) at $60^{\circ} \mathrm{C}$ for $1 \mathrm{~h}$ and following vacuum-microwave finishing drying (VMFD) at $360 \mathrm{~W}(\mathbf{c})$. 
Table 1. Model parameters $\left(a, k_{1}, b, k_{2}\right)$; maximum temperature of the hemp flowers during drying (TMax); and drying times $\mathrm{t}_{\mathrm{CD}}$ and $\mathrm{t}_{\mathrm{VMD}}$ of $\mathrm{CD}$ and $\mathrm{VMD}$, respectively.

\begin{tabular}{|c|c|c|c|c|c|c|c|c|c|}
\hline \multirow{2}{*}{ Drying Methods } & \multicolumn{4}{|c|}{ Parameters } & \multicolumn{2}{|c|}{ Statistics } & \multicolumn{2}{|c|}{ Drying Time (min) } & \multirow[b]{2}{*}{$\mathrm{T}_{\text {Max }}\left({ }^{\circ} \mathrm{C}\right)$} \\
\hline & $a$ & $\begin{array}{c}k_{1} \\
\left(\mathrm{~min}^{-1}\right)\end{array}$ & $b$ & $\begin{array}{c}k_{2} \\
\left(\min ^{-1}\right)\end{array}$ & RMSE & $R^{2}$ & $t_{C D}$ & $t_{\mathrm{VMD}}$ & \\
\hline CD50 & 0.54412 & 0.02469 & 0.44193 & 0.00350 & 0.00537 & 0.9997 & 840 & - & 50 \\
\hline CD60 & 0.58617 & 0.03623 & 0.40373 & 0.00521 & 0.00692 & 0.9995 & 660 & - & 60 \\
\hline CD70 & 0.53544 & 0.06093 & 0.46011 & 0.00912 & 0.00810 & 0.9993 & 510 & - & 70 \\
\hline VMD240 & 0.95054 & 0.08296 & 0.11951 & 0.00742 & 0.03445 & 0.9827 & - & 112 & 59 \\
\hline VMD360 & 0.91787 & 0.11572 & 0.12779 & 0.01484 & 0.02596 & 0.9903 & - & 78 & 54 \\
\hline VMD480 & 1.04449 & 0.12333 & 0.01818 & 0.00014 & 0.03465 & 0.9883 & - & 40 & 61 \\
\hline CPD-VMFD & 0.29965 & 0.12680 & 0.06519 & 0.01216 & 0.00785 & 0.9938 & 60 & 54 & 55 \\
\hline
\end{tabular}

The two-term model was used to describe the drying kinetics of hemp flowers. The good fit of this model was confirmed by high values of coefficient of determination $\left(R^{2}>0.98\right.$ for all the drying methods) and low values of RMSE (Table 1). The model was previously successfully used in studies on pomegranate rind and arils [32] and ginger slices [33]. This was due to the model structure that specifically describes two stages of drying, with coefficient $a$ referring to the breadth of the first stage of drying where intensive evaporation occurs, illustrated by high values of drying constant $k_{1}$, and the second stage (coefficient $b$ ), with decreasing drying rate characterized by low values of drying constant $k_{2}$. On the other hand, $1 / k_{1}$ and $1 / k_{2}$ are time constants that express the time required for $37 \%$ decrease of $a$ and $b$ values, respectively [34]. Therefore, it can be stated that the higher the value of the drying constant $k_{1}$ or $k_{2}$, the lower the value of the time constant $1 / k_{1}$ or $1 / k_{2}$ and thus the shorter the time of the relevant stage of drying.

It is worth mentioning that during the first stage of drying, the mass transfer mainly consists of water evaporation from the surface of the material at a high drying rate assured by sufficient water diffusion at a relatively high external moisture content, whereas during the second stage of drying, the mass transfer occurs at a lower drying rate limited by internal water diffusion hindered by decreasing moisture content [5]. The drying kinetics of CD might be affected to some extend by shrinkage of the dried material manifested by curling of the whole flower at the end of the first stage of drying, leading to a decrease of surface evaporation and thus hindering the mass transfer, which results in the reduction of drying rate. It can be seen that the change of temperature of hot air during convective drying (from 50 to $70^{\circ} \mathrm{C}$ ) results in an increase of drying rate followed by higher values of $k_{1}$ and $k_{2}$ constants (increase from $k_{1}=0.02469 \mathrm{~min}^{-1}$ in case of CD50 to $k_{1}=0.06093 \mathrm{~min}^{-1}$ in the case of CD70 during first stage of drying). Similar behavior was previously reported in studies on orange slices [35] and red pepper [36].

As for VMD, it should be noted that values of coefficient $a$ were very high (over 0.9 ), which means that most of the drying occurred in the first stage, while coefficient $b$ was over nine times lower than coefficient $a$, which marks shorter period of the second stage of drying. Moreover, with higher microwave power, $k_{1}$ constant increased, which shows that the drying rate was greatly influenced by the power of magnetrons in the first stage of drying. However, in the second stage of drying, the drying rate decreased with an increase of microwave power. It was due to the extended first phase of the process (defined by coefficient $a$ ) with high $k_{1}$ values that mostly contributed to the water evaporation and reduction of moisture content and thus moisture ratio (MR). Still, the second stage greatly affected the drying kinetics and the time of the process, even though it had little impact on MR values, which decreased at low rate. The course of drying curves showed that application of $480 \mathrm{~W}$ instead of $360 \mathrm{~W}$ did not contribute to an increase of the drying rate at the initial phase of drying, which was confirmed by similar values of $k_{1}$ amounting to 0.1157 and 0.1233 , respectively. This means that from a practical point of view, starting with a microwave power higher than $360 \mathrm{~W}$ is not reasonable during VMD of hemp flowers. However, the elevation of microwave power from 360 to $480 \mathrm{~W}$ is reasonable after the initial phase of VMD lasting around $8 \mathrm{~min}$ (Figure 1b). It can be presumed that during the initial phase of VMD at high microwave power, the water removal rate was 
restricted by the increased resistance of mass transfer caused by the thickening of the water molecules in the outer layer of the material as a result of a transport mechanism of the Darcy type [37] that had too much intense pressure at the limited possibility of water evaporation from the surface of the dried material. From this perspective, shrinkage of the dried material described above additionally hindered water evaporation from the decreased surface area and promoted the thickening of the water molecules in the outer layer of the material.

In case of CPD-VMFD, convective pre-drying can be easily described by the model parameters fitted and adjusted for $\mathrm{CD}$ at $60^{\circ} \mathrm{C}$; thus, only vacuum-microwave finishing drying is provided in Table 1. During combined drying, the most intensive evaporation occurred throughout the pre-drying period, and therefore the joint contribution of finishing drying (defined as the sum of $a$ and $b$ coefficients) was quite low. However, the drying constant $k_{1}$ reached the highest value $\left(0.12680 \mathrm{~min}^{-1}\right)$ among all applied drying methods, which was almost $10 \%$ more than in the case of the sole use of VMD360, while $k_{2}$ was also very high and was only lower than in the case of VMD360. The relatively high values of $k_{1}$ and $k_{2}$ may be somewhat surprising, taking into account the fact that VMFD started when the surface of plant material had been already reduced due to the shrinkage formed during CPD. This can be explained by the recovery of the water molecule distribution within the entire volume of the pre-dried material during the time necessary to reload the sample.

Obtained data show that an increase of drying temperature resulted in shorter drying times during $\mathrm{CD}$. An increase by $20^{\circ} \mathrm{C}$ (from 50 to $70{ }^{\circ} \mathrm{C}$ ) resulted in $39 \%$ time reduction (from 840 to $510 \mathrm{~min}$ ), which is consistent with previous studies on true lavender leaves [38], carrot slices [39], and cornelian cherry fruit [40]. Moreover, VMD was much shorter than CD. This was due to the volumetric heating occurring during VMD that sped up the process by increasing the temperature inside of the sample [41,42]. As a result, samples treated by VMD at $480 \mathrm{~W}$ were dried 21 times faster when compared to $\mathrm{CD}$ at $50{ }^{\circ} \mathrm{C}$. Furthermore, the power of magnetrons during VMD influenced water removal and resulted in shorter processing times when higher powers were applied [43]; namely, an increase from $240 \mathrm{~W}$ to $480 \mathrm{~W}$ decreased the time of drying by $72 \mathrm{~min}$ (reduction from 112 to $40 \mathrm{~min}$ for VMD at $240 \mathrm{~W}$ and VMD at $480 \mathrm{~W}$, respectively).

On the other hand, combined methods (CPD-VMFD) resulted in a much shorter time of drying compared to $C D$, yet were still longer than VMD, which is consistent with previous studies on pomegranate arils [32] and quinces [44]. This method proved to be beneficial in other studies, i.e., on sweet basil [8] and thyme [6], where high quality products were obtained in a significantly shorter time period (compared to CD).

It is worth noting that the duration of VMD did not depend on the maximal temperature $\left(\mathrm{T}_{\mathrm{Max}}\right)$ of the samples treated by microwaves. Usually the maximal temperature is achieved by VMD samples at the end of drying when the heat energy generated by water dipoles in the microwave field are in excess the energy necessary for water evaporation [45]. In the case of VMD of hemp flowers, the highest values of $\mathrm{T}_{\mathrm{Max}}$, amounting to 61 and $59^{\circ} \mathrm{C}$, were obtained at 480 and $240 \mathrm{~W}$, respectively. The relatively high value of $\mathrm{T}_{\mathrm{Max}}$ for samples dried at $240 \mathrm{~W}$ can be explained by the longer exposition to microwave radiation and thus the accumulation of the heat energy delivered at low microwave power [9]. The lowest values of $\mathrm{T}_{\mathrm{Max}}$, amounting to 61 and $59{ }^{\circ} \mathrm{C}$, were found for VMD360 and CPD-VMFD, respectively. During both the drying protocols, the same microwave power of $360 \mathrm{~W}$ was applied, which suggests that the mean value of microwave wattage maintained the thermal energy balance at the lowest temperature of VMD material. Generally, the temperature of VMD herbal products is relatively low due to their specific morphological structure, preventing the excessive increase of inner pressure caused by microwave heating [6].

It can be seen that all the applied drying protocols differed in terms of the form of heat energy delivery, duration, and dried material temperature. Therefore, it is crucial to evaluate these drying protocols also in terms of their impact on the color, chemical composition, and sensory attributes of hemp flowers. 


\subsection{Color Analysis}

Color of the samples is presented in the Table 2. The drying process increased lightness, yellowness, and greenness of the samples, which was confirmed by higher values of parameters $L^{*}$ and $b^{*}$ and lower values of $a^{*}$ parameter. The lightest samples (highest $L^{*}$ values) with yellowest hues (one of the lowest values of $a^{*}$ parameter) were obtained after being subjected to VMD at $480 \mathrm{~W}$. On the other hand, samples of VMD at $240 \mathrm{~W}$ were significantly darker (lowest $L^{*}$ ) than the samples obtained by other drying methods. Moreover, VMD at $360 \mathrm{~W}$ resulted in the greenest samples (highest values of $\left.a^{*}\right)$ and lowest values of $b^{*}$ parameter, which had yellow hues. Generally, an increase of temperature during $C D$ resulted in the obtaining of darker samples with a higher share of green and yellow hues, despite a slight decrease in $a^{*}$ and $b^{*}$ values. Although a similar effect on greenness and yellowness was observed when increasing the microwave power during VMD, these color alterations were associated with lightening of the samples. It is worth noting that the values of the color parameters determined for CPD-VMFD samples were between the relevant values obtained for samples dried by $\mathrm{CD}$ at $60^{\circ} \mathrm{C}$ and VMD at $360 \mathrm{~W}$. The significance of the color changes can be estimated by the values of total color change $\Delta E^{*}$. According to Sumic at al. [46], if $\Delta E^{*}$ is less than 1.0, it is assumed that the difference in color would not be perceptible by the human eye. The total color change of the dried samples was much higher than 1.0 for all cases. However, the lowest change of 19.2 was stated for the VMD240 sample, whereas the highest change of 24.20 was found for the VMD480 sample. This indicates that microwave power during VMD had a higher impact on the color change of the dried material than hot air temperature during $\mathrm{CD}$.

Table 2. Color parameters of hemp flowers subjected to drying using different methods.

\begin{tabular}{ccccc}
\hline \multirow{2}{*}{ Drying Method } & \multicolumn{4}{c}{ Color } \\
\cline { 2 - 5 } & $\boldsymbol{L}^{*}$ & $\boldsymbol{a}^{*}$ & $\boldsymbol{b}^{*}$ & $\boldsymbol{\Delta} \boldsymbol{E}^{*}$ \\
\hline Fresh & $20.61 \pm 5.37$ & $-1.98 \pm 0.61$ & $8.41 \pm 2.87$ & - \\
CD50 & $42.48 \pm 1.59^{\mathrm{a}, \mathrm{b}, 1}$ & $-4.49 \pm 0.83^{\mathrm{a}, \mathrm{b}}$ & $12.06 \pm 1.01^{\mathrm{a}, \mathrm{b}}$ & 22.31 \\
CD60 & $41.88 \pm 0.7^{\mathrm{a}, \mathrm{c}}$ & $-4.99 \pm 0.6^{\mathrm{a}}$ & $10.77 \pm 0.4^{\mathrm{a}, \mathrm{c}}$ & 21.61 \\
CD70 & $41.72 \pm 1.26^{\mathrm{a}, \mathrm{c}}$ & $-4.82 \pm 0.25^{\mathrm{a}}$ & $11.25 \pm 0.72^{\mathrm{a}, \mathrm{b}}$ & 21.49 \\
VMD240 & $39.78 \pm 0.43^{\mathrm{c}}$ & $-3.57 \pm 0.66^{\mathrm{b}}$ & $9.6 \pm 0.34^{\mathrm{c}}$ & 19.27 \\
VMD360 & $43.56 \pm 1.28^{\mathrm{a}, \mathrm{b}}$ & $-3.5 \pm 0.62^{\mathrm{b}}$ & $11.34 \pm 0.61^{\mathrm{a}, \mathrm{b}}$ & 23.19 \\
VMD480 & $44.27 \pm 0.93^{\mathrm{b}}$ & $-4.83 \pm 0.37^{\mathrm{a}}$ & $12.62 \pm 0.57^{\mathrm{b}}$ & 24.20 \\
CPD-VMFD & $42.09 \pm 1.09^{\mathrm{a}, \mathrm{b}}$ & $-4.59 \pm 0.52^{\mathrm{a}, \mathrm{b}}$ & $10.99 \pm 1.14^{\mathrm{a}, \mathrm{c}}$ & 21.79 \\
\hline
\end{tabular}

${ }^{1}$ Mean values followed by the same letter were not significantly different $(p<0.05)$ according to the HSD Tukey's least significance difference test.

\subsection{Volatile Constituents of Fresh Cannabis sativa Flowers}

Analysis of GC-MS of the distilled essential oils from the hemp flower revealed 93 peaks, which were considered to be volatile substances (chromatograms from the GC-MS analysis of volatile compounds content of hemp flowers are available in supplementary data; Figures S1 and S2). These compounds are collected in Table 3. Of all the volatile components identified in the tested samples of hemp flowers, we could distinguish the following main substances: $\beta$-myrcene $(26.66 \%)$, $\beta$-(E)-caryophyllene $(17.50 \%)$, limonene $(10.45 \%), \alpha$-humulene $(7.26 \%)$, caryophyllene oxide $(3.79 \%)$, $\beta$-pinene $(2.51 \%)$, terpinolene $(2.50 \%)$, and $\alpha$-pinene $(2.16 \%)$. In smaller quantities, $(\mathrm{E}, \mathrm{E})-\alpha$-farnesene $(1.80 \%), \alpha$-selinene $(1.65 \%), \beta$-chamigrene $(1.41 \%)$, humulene epoxide II $(1.25 \%)$, pseudowiddrene $(1.24 \%)$, and $\beta$-trans-ocimene $(1.12 \%)$ were identified. The substances above have a considerable influence on the fragrance quality of the hemp flowers.

In previous studies, similar results were found, where the identified compounds were as follows: $\beta$-(E)-caryophyllene (23.8\%), $\alpha$-pinene (16.4\%), and $\beta$-myrcene (14.2\%). The remaining compounds worth showing had the following percentages: terpinolene $(9.6 \%), \alpha$-humulene $(8.3 \%), \beta$-pinene $(5.2 \%), \beta-(E)$-ocimene $(5.1 \%)$, and $\beta-(E)$-farnesene (3.0\%) [47]. Benelli in other studies also showed a 
similar profile of volatile components to those mentioned above, where $\beta$-(E)-caryophyllene $(21.4 \%)$, $\beta$-myrcene (11.3\%), $\alpha$-pinene (7.8\%), terpinolene $(7.6 \%), \alpha$-humulene $(7.1 \%), \beta$-(E)-ocimene $(3.9 \%)$, and $\beta$-pinene (2.9\%) were identified as the most representative compounds [48].

Considering the analysis of the obtained fractions, we observed a similarity with the paper published by Nissen. Depending on the cannabis cultivar, the following substances can be distinguished, $\beta$-myrcene (12.46-29.22\%), $\alpha$-pinene (10.9-16.99\%), $\beta$-(E)-caryophyllene (10.56-13.90\%), $\beta$-pinene (6.38-9.33\%), $\alpha$-humulene (4.84-6.71\%), terpinolene (3.42-10.73\%), limonene (3.11-4.99\%), and $\beta-(E)$-ocimene $(2.03-9.34 \%)$ as those occurring in the highest amount [17]. Mediavilla and Steinemann also studied the profile of volatile compounds on different cannabis strains. The main compounds isolated were $\beta$-myrcene $(29.4-65.8 \%), \beta-(E)$-caryophyllene $(3.8-37.5 \%)$, $\alpha$-pinene $(2.3-31.0 \%)$, terpinolene $(0.4-23.8 \%), \beta-(E)$-ocimene $(0.3-10.2 \%), \alpha$-humulene $(0.7-7.9 \%)$, $\beta$-pinene (0.6-7.8\%), and limonene (0.2-6.9\%) [49]. Iseppi et al. reported $\beta$-myrcene (4.5-39.2\%), $\beta$-(E)-caryophyllene (8.5-29.8\%), $\beta$-pinene (4.8-25.4\%), terpinolene (1.9-9.6\%), $\alpha$-pinene $(3.4-8.2 \%)$, $\beta$ - $(E)$-ocimene $(2.2-7.1 \%), \alpha$-humulene $(2.2-6.6 \%)$, and limonene $(0.1-5.7 \%)$ as the main volatile components of hemp flower essential oils. These discrepancies may result from the use of different cultivars for research and from the condition of raw material [50].

Table 3. Complete volatile constituents of fresh Cannabis sativa flowers.

\begin{tabular}{|c|c|c|c|c|c|c|}
\hline \multirow{2}{*}{ Compound } & \multirow{2}{*}{$\begin{array}{c}\text { RT } \\
(\mathrm{min})\end{array}$} & \multicolumn{4}{|c|}{ Retention Indices (RI) } & \multirow{2}{*}{ Content $(\%)^{5}$} \\
\hline & & RI_lit ${ }^{1}$ & RI_lit ${ }^{2}$ & RI_lit ${ }^{3}$ & RI_exp ${ }^{4}$ & \\
\hline Octane & 4.585 & 800 & 800 & 800 & 800 & $0.08 \pm 0.01$ \\
\hline (2E)-2-Hexenal & 6.130 & 855 & 851 & 850 & 855 & $\operatorname{tr}^{6}$ \\
\hline (3Z)-3-Hexen-1-ol & 6.240 & 859 & 857 & 853 & 857 & $0.06 \pm 0.02$ \\
\hline 1-Hexanol & 6.705 & 870 & 868 & 867 & 869 & $\operatorname{tr}$ \\
\hline 2-Heptanone & 7.485 & 892 & 891 & 892 & 890 & $0.05 \pm 0.01$ \\
\hline Heptanal & 7.900 & 902 & 901 & 906 & 900 & $0.51 \pm 0.12$ \\
\hline$(2 E, 4 E)-2,4-H e x a d i e n a l$ & 8.395 & 909 & 911 & 914 & 909 & $\operatorname{tr}$ \\
\hline Artemisia triene & 8.620 & 929 & 929 & 922 & 926 & $0.50 \pm 0.21$ \\
\hline$\alpha$-Thujene & 9.035 & 930 & 929 & 927 & 928 & $0.06 \pm 0.08$ \\
\hline$\alpha$-Pinene & 9.310 & 939 & 937 & 933 & 932 & $2.16 \pm 0.82$ \\
\hline Fenchene & 9.985 & 952 & 952 & 948 & 953 & $0.25 \pm 0.05$ \\
\hline Benzaldehyde & 10.585 & 960 & 962 & 960 & 960 & $\operatorname{tr}$ \\
\hline (2E)-2-Hepten-1-ol & 11.025 & 965 & 978 & 964 & 970 & $\operatorname{tr}$ \\
\hline Sabinene & 11.290 & 975 & 974 & 972 & 976 & $\operatorname{tr}$ \\
\hline$\beta$-Pinene & 11.400 & 979 & 979 & 978 & 976 & $2.51 \pm 0.32$ \\
\hline trans-Isolimonene & 11.815 & 984 & 983 & 984 & 983 & $\operatorname{tr}$ \\
\hline 6-Methyl-5-hepten-2-one & 12.115 & 985 & 985 & 986 & 987 & $\operatorname{tr}$ \\
\hline$\beta$-Myrcene & 12.455 & 990 & 991 & 991 & 994 & $26.66 \pm 1.79$ \\
\hline$\alpha$-Phellandrene & 12.970 & 1002 & 1005 & 1007 & 1004 & $0.13 \pm 0.06$ \\
\hline 3-Carene & 13.280 & 1011 & 1011 & 1009 & 1007 & $0.12 \pm 0.09$ \\
\hline$\alpha$-Terpinene & 13.665 & 1017 & 1017 & 1018 & 1017 & $0.12 \pm 0.03$ \\
\hline o-Cymene & 13.910 & 1026 & 1022 & 1024 & 1021 & $\operatorname{tr}$ \\
\hline p-Cymene & 14.115 & 1024 & 1030 & 1025 & 1025 & $\operatorname{tr}$ \\
\hline Limonene & 14.415 & 1029 & 1030 & 1030 & 1030 & $10.45 \pm 1.21$ \\
\hline Sylvestrene & 14.745 & 1030 & 1027 & 1031 & 1035 & $\operatorname{tr}$ \\
\hline$\beta$-cis-Ocimene & 15.055 & 1037 & 1038 & 1035 & 1041 & $0.09 \pm 0.03$ \\
\hline$\beta$-trans-Ocimene & 15.660 & 1050 & 1049 & 1046 & 1051 & $1.12 \pm 0.14$ \\
\hline Prenyl isobutyrate & 15.930 & 1052 & 1052 & 1050 & 1052 & $\operatorname{tr}$ \\
\hline Oct-(3Z)-enol & 16.025 & 1054 & 1059 & 1059 & 1054 & $\operatorname{tr}$ \\
\hline$\gamma$-Terpinene & 16.205 & 1059 & 1060 & 1058 & 1062 & $0.14 \pm 0.07$ \\
\hline cis-Sabinene hydrate & 16.695 & 1070 & 1070 & 1069 & 1071 & $0.14 \pm 0.09$ \\
\hline 2-trans-Octenol & 17.285 & 1074 & 1072 & 1073 & 1075 & $0.05 \pm 0.01$ \\
\hline Terpinolene & 18.030 & 1088 & 1088 & 1086 & 1087 & $2.50 \pm 0.43$ \\
\hline 6,7-Epoxymyrcene & 18.445 & 1092 & 1090 & 1096 & 1091 & $0.06 \pm 0.02$ \\
\hline trans-Sabinene hydrate & 18.650 & 1094 & 1093 & 1099 & 1096 & $\operatorname{tr}$ \\
\hline Linalool & 18.895 & 1096 & 1099 & 1101 & 1099 & $0.09 \pm 0.11$ \\
\hline Nonanal & 19.150 & 1100 & 1104 & 1107 & 1105 & $0.32 \pm 0.14$ \\
\hline Fenchol & 19.565 & 1116 & 1113 & 1119 & 1116 & $0.82 \pm 0.03$ \\
\hline trans-Pinene hydrate & 20.025 & 1122 & 1120 & 1121 & 1118 & $0.82 \pm 0.21$ \\
\hline cis-Pinene hydrate & 21.340 & 1143 & 1143 & 1144 & 1139 & $0.11 \pm 0.07$ \\
\hline$\beta$-Terpineol & 21.720 & 1144 & 1144 & 1149 & 1145 & $0.06 \pm 0.01$ \\
\hline Ipsdienol & 21.875 & 1145 & 1147 & 1146 & 1147 & $0.1 \pm 0.02$ \\
\hline Myrcenone & 22.000 & 1149 & 1145 & 1149 & 1150 & $0.09 \pm 0.10$ \\
\hline
\end{tabular}


Table 3. Cont.

\begin{tabular}{|c|c|c|c|c|c|c|}
\hline \multirow{2}{*}{ Compound } & \multirow{2}{*}{$\begin{array}{c}\text { RT } \\
(\mathrm{min})\end{array}$} & \multicolumn{4}{|c|}{ Retention Indices (RI) } & \multirow{2}{*}{ Content $(\%)^{5}$} \\
\hline & & RI_lit ${ }^{1}$ & RI_lit ${ }^{2}$ & RI_lit ${ }^{3}$ & RI_exp ${ }^{4}$ & \\
\hline$\alpha$-Pinene oxide & 22.635 & 1159 & 1157 & 1156 & 1158 & $0.09 \pm 0.05$ \\
\hline 3-Thujanol & 23.005 & 1168 & 1167 & 1169 & 1165 & $0.09 \pm 0.03$ \\
\hline Terpinen-4-ol & 23.740 & 1177 & 1177 & 1177 & 1177 & $0.12 \pm 0.09$ \\
\hline Isogeranial & 23.880 & 1180 & 1182 & 1179 & 1177 & $\operatorname{tr}$ \\
\hline$\alpha$-Terpineol & 24.670 & 1188 & 1189 & 1195 & 1189 & $0.43 \pm 0.12$ \\
\hline Hexyl butanoate & 25.035 & 1192 & 1192 & 1195 & 1194 & $0.14 \pm 0.07$ \\
\hline trans-4-Caranone & 25.530 & 1196 & 1197 & 1200 & 1196 & $\operatorname{tr}$ \\
\hline Bornyl acetate & 30.975 & 1285 & 1285 & 1285 & 1282 & $\operatorname{tr}$ \\
\hline$\alpha$-Cubebene & 35.095 & 1351 & 1351 & 1349 & 1345 & $\operatorname{tr}$ \\
\hline$\alpha$-Ylangene & 36.410 & 1375 & 1372 & 1371 & 1368 & $0.12 \pm 0.01$ \\
\hline$\alpha$-Copaene & 36.700 & 1376 & 1376 & 1375 & 1373 & $\operatorname{tr}$ \\
\hline Hexyl hexanoate & 37.405 & 1383 & 1384 & 1387 & 1383 & $\operatorname{tr}$ \\
\hline 7-epi-Sesquithujene & 37.705 & 1391 & 1402 & 1389 & 1387 & $0.07 \pm 0.03$ \\
\hline Isocaryophyllene & 38.610 & 1408 & 1406 & 1405 & 1402 & $0.54 \pm 0.12$ \\
\hline$\alpha$-Gurjunene & 38.800 & 1409 & 1409 & 1406 & 1404 & $\operatorname{tr}$ \\
\hline$\beta$-(E)-Caryophyllene & 39.480 & 1419 & 1419 & 1424 & 1415 & $17.50 \pm 1.75$ \\
\hline$\beta$-Duprezianene & 39.735 & 1422 & 1422 & 1427 & 1420 & $0.09 \pm 0.03$ \\
\hline$\alpha$-trans-Bergamotene & 40.560 & 1434 & 1435 & 1432 & 1435 & $0.17 \pm 0.09$ \\
\hline$\beta$-Humulene & 40.660 & 1438 & 1440 & 1440 & 1435 & $0.11 \pm 0.05$ \\
\hline Guaia-6,9-diene & 40.925 & 1444 & 1443 & 1444 & 1440 & $0.17 \pm 0.11$ \\
\hline$\alpha$-Humulene & 41.485 & 1454 & 1454 & 1454 & 1453 & $7.26 \pm 1.48$ \\
\hline Khusimene & 41.650 & 1455 & 1451 & 1451 & 1455 & $0.21 \pm 0.14$ \\
\hline$\beta$-(E)-Farnesene & 41.870 & 1456 & 1457 & 1452 & 1457 & $0.33 \pm 0.21$ \\
\hline 9-epi-(E)-Caryophyllene & 41.985 & 1464 & 1466 & 1464 & 1459 & $0.39 \pm 0.18$ \\
\hline Dodec-(2E)-enal & 42.380 & 1466 & 1468 & 1469 & 1464 & $0.15 \pm 0.08$ \\
\hline$\gamma$-Gurjunene & 42.865 & 1474 & 1475 & 1476 & 1473 & $0.10 \pm 0.01$ \\
\hline$\beta$-Chamigrene & 43.290 & 1477 & 1476 & 1479 & 1479 & $1.41 \pm 0.56$ \\
\hline$\gamma$-Selinene & 43.425 & 1479 & 1479 & 1480 & 1481 & $0.62 \pm 0.19$ \\
\hline$\alpha$-Selinene & 43.990 & 1496 & 1494 & 1495 & 1490 & $1.65 \pm 0.77$ \\
\hline$\alpha$-Zingiberene & 44.330 & 1498 & 1495 & 1496 & 1495 & $0.31 \pm 0.16$ \\
\hline$\delta$-Amorphene & 44.785 & 1504 & 1505 & 1506 & 1499 & $0.38 \pm 0.09$ \\
\hline$(E, E)$ - $\alpha$-Farnesene & 45.100 & 1505 & 1508 & 1504 & 1509 & $1.80 \pm 0.64$ \\
\hline Pseudowiddrene & 45.385 & 1509 & 1510 & 1510 & 1512 & $1.24 \pm 0.57$ \\
\hline$\delta$-Cadinene & 45.755 & 1523 & 1524 & 1518 & 1514 & $0.21 \pm 0.03$ \\
\hline$\gamma$-Cuprenene & 46.320 & 1533 & 1532 & 1530 & 1532 & $0.56 \pm 0.12$ \\
\hline Selina-4(15),7(11)-diene & 46.575 & 1546 & 1542 & 1540 & 1533 & $2.13 \pm 0.86$ \\
\hline$\alpha$-Cadinene & 46.705 & 1538 & 1538 & 1538 & 1538 & $0.82 \pm 0.31$ \\
\hline (E)- $\alpha$-Bisabolene & 47.025 & - & 1512 & 1540 & 1538 & $0.28 \pm 0.16$ \\
\hline cis-Muurol-5-en-4- $\beta$-ol & 47.300 & 1551 & 1549 & 1548 & 1548 & $0.07 \pm 0.03$ \\
\hline Germacrene B & 47.555 & 1561 & 1557 & 1557 & 1551 & $0.16 \pm 0.05$ \\
\hline Lippifoli-1(6)-en-5-one & 47.995 & 1552 & 1553 & 1551 & 1557 & $0.69 \pm 0.32$ \\
\hline epi-Longipinanol & 48.310 & 1563 & 1566 & 1558 & 1564 & $0.44 \pm 0.11$ \\
\hline Caryophyllene oxide & 49.055 & 1583 & 1581 & 1581 & 1576 & $3.79 \pm 0.44$ \\
\hline Humulene epoxide I & 49.965 & - & 1604 & 1604 & 1590 & $0.18 \pm 0.05$ \\
\hline Humulene epoxide II & 50.540 & 1608 & 1606 & 1613 & 1607 & $1.25 \pm 0.14$ \\
\hline 1,10-di-epi-Cubenol & 51.115 & 1619 & 1615 & 1614 & 1612 & $0.62 \pm 0.23$ \\
\hline epi- $\gamma$-Eudesmol & 51.455 & 1623 & 1622 & 1624 & 1623 & $0.64 \pm 0.45$ \\
\hline$\alpha$-Acorenol & 51.935 & 1633 & 1631 & 1632 & 1633 & $0.14 \pm 0.04$ \\
\hline Caryophylla-4(12),8(13)-dien-5 $\alpha$-ol & 52.350 & 1640 & 1637 & 1642 & 1646 & $0.80 \pm 0.23$ \\
\hline$\alpha$-Bisabolol & 54.140 & 1685 & 1684 & 1688 & 1686 & $0.44 \pm 0.13$ \\
\hline
\end{tabular}

\subsection{Effects of Different Drying Methods on the Volatile Compound Content in Cannabis sativa}

In the conducted studies of the biological material consisting of fresh hemp flowers, we found that the content of essential oil was $0.21 \mathrm{~g} / 100 \mathrm{~g}^{-1}$ of dry weight (DW). Considering the yield of essential oils in cannabis flowers, we can conclude that it was high, as $0.1-0.25 \%$ [17] and $0.25 \%$ [51] of essential oils were reported in previous studies. Furthermore, Liang et al. [52] and Chalchat and Özcan [53] reported the yield of essential oils in the inflorescences of sage and basil as $0.2 \%$ and $0.5 \%$, respectively. A comparison of changes in the content of 11 main volatile components in hemp with reference to different drying methods is shown in Table 4. As far as the total content of essential oils is concerned, it is not analogous to the 11 main compounds, as they represent $77.88 \%$ of the total. 
Table 4. Comparison of changes in volatile composition of fresh and dried hemp flowers.

\begin{tabular}{|c|c|c|c|c|c|c|c|c|}
\hline \multirow{3}{*}{ Compound } & \multicolumn{8}{|c|}{ Drying Method } \\
\hline & Fresh $^{1}$ & $\mathrm{CD} 50^{\circ} \mathrm{C}$ & $\mathrm{CD} 60^{\circ} \mathrm{C}$ & $\mathrm{CD} 70^{\circ} \mathrm{C}$ & VMD $240 \mathrm{~W}$ & VMD $360 \mathrm{~W}$ & VMD $480 \mathrm{~W}$ & CPD-VMFD \\
\hline & \multicolumn{8}{|c|}{ Content (\%) } \\
\hline$\alpha$-Pinene & $2.16^{a, 3}$ & $10.79 \mathrm{~g}$ & $7.16^{\mathrm{e}}$ & $8.27^{\mathrm{e}}$ & $3.67^{\mathrm{b}}$ & $5.86^{\mathrm{d}}$ & $9.58^{f}$ & $11.13^{g}$ \\
\hline$\beta$-Pinene & $2.51^{\mathrm{a}}$ & $4.47^{\mathrm{a}}$ & $3.49^{c}$ & $4.43^{\mathrm{d}}$ & $2.17^{\mathrm{a}}$ & $2.89^{b}$ & $4.96^{\mathrm{e}}$ & $5.12^{\mathrm{e}}$ \\
\hline$\beta$-Myrcene & $26.66^{a}$ & $9.95^{f}$ & $10.34^{\mathrm{e}}$ & $19.27^{b}$ & $10.78^{\mathrm{e}}$ & $7.54 \mathrm{~g}$ & $13.03^{\mathrm{d}}$ & $16.88^{c}$ \\
\hline Limonene & $10.45^{\mathrm{a}}$ & $2.17^{\mathrm{e}}$ & $2.16^{\mathrm{e}}$ & $4.13^{b}$ & $3.55^{\mathrm{c}}$ & $1.58^{\mathrm{g}}$ & $2.02^{\mathrm{f}}$ & $2.77^{\mathrm{d}}$ \\
\hline$\beta$-trans-Ocimene & $1.12^{\mathrm{a}}$ & $0.80^{\mathrm{d}}$ & $0.62^{\mathrm{e}}$ & $0.99^{b}$ & $0.50^{f}$ & $0.78^{\mathrm{d}}$ & $0.68^{\mathrm{e}}$ & $0.92^{c}$ \\
\hline Terpinolene & $2.50^{\mathrm{a}}$ & $0.97^{\mathrm{e}}$ & $1.60^{\mathrm{b}}$ & $1.66^{\mathrm{b}}$ & $0.69^{\mathrm{f}}$ & $0.29 \mathrm{~g}$ & $1.25^{\mathrm{c}}$ & $1.29^{c}$ \\
\hline$\beta-(E)$-Caryophyllene & $17.50^{\mathrm{a}}$ & $25.35^{e}$ & $23.41^{\mathrm{c}}$ & $17.91^{\mathrm{a}}$ & $24.26^{\mathrm{d}}$ & $22.62^{b}$ & $16.92^{\mathrm{a}}$ & $24.24^{\mathrm{d}}$ \\
\hline$\alpha$-Humulene & $7.26^{\mathrm{a}}$ & $11.51^{\mathrm{e}}$ & $9.62^{c}$ & $7.22^{\mathrm{a}}$ & $9.23^{c}$ & $8.90^{\mathrm{b}}$ & $8.41^{\mathrm{b}}$ & $10.32^{\mathrm{d}}$ \\
\hline$(E, E)$ - $\alpha$-Farnese & $1.80^{\mathrm{a}}$ & $1.82^{\mathrm{a}}$ & $0.58^{\mathrm{e}}$ & $1.05^{\mathrm{d}}$ & $1.14^{\mathrm{c}}$ & $1.44^{\mathrm{b}}$ & $1.48^{\mathrm{b}}$ & $1.03^{\mathrm{d}}$ \\
\hline Selina-4(15),7(11)-diene & $2.13^{\mathrm{a}}$ & $1.21^{\mathrm{f}}$ & $1.20^{\mathrm{f}}$ & $1.35^{\mathrm{e}}$ & $1.96^{\mathrm{b}}$ & $1.43^{\mathrm{d}}$ & $1.52^{c}$ & $1.47^{\mathrm{d}}$ \\
\hline Caryophyllene oxide & $3.79^{\mathrm{a}}$ & $4.96^{b}$ & $7.82^{\mathrm{c}}$ & $10.71^{\mathrm{e}}$ & $11.04^{\mathrm{e}}$ & $8.65^{\mathrm{d}}$ & $12.16^{\mathrm{f}}$ & $5.84^{b}$ \\
\hline EO yield ${ }^{2}$ & $0.21^{\mathrm{a}}$ & $0.16^{\mathrm{c}}$ & $0.14^{d}$ & $0.12^{\mathrm{e}}$ & $0.18^{b}$ & $0.15^{d}$ & $0.15^{d}$ & $0.11^{\mathrm{e}}$ \\
\hline$\%$ recovery of EO & 100 & 76.19 & 66.67 & 57.14 & 85.71 & 71.42 & 71.42 & 52.38 \\
\hline
\end{tabular}

${ }^{1}$ Dry mass calculated; ${ }^{2} \mathrm{~mL} / 100 \mathrm{~g}^{-1}$ according to distillation on Deryng apparatus; ${ }^{3}$ values followed by the same letter within a row are not significantly different $(p>0.05$, Duncan's test).

By analyzing the content of essential oils in relation to different drying processes, we observed that each of them had an impact on its final yield. VMD at $240 \mathrm{~W}\left(0.18 \mathrm{~g} / 100 \mathrm{~g}^{-1}\right)$ turned out to be the most effective drying method, followed by $\mathrm{CD}$ at $50{ }^{\circ} \mathrm{C}\left(0.16 \mathrm{~g} / 100 \mathrm{~g}^{-1}\right)$, while VMD at $360 \mathrm{~W}$ and VMD at 480 were the next methods with the same oil yield $\left(0.15 \mathrm{~g} / 100 \mathrm{~g}^{-1}\right)$. The least effective method was CPD-VMFD, with an essential oil yield of only $0.11 \mathrm{~g} / 100 \mathrm{~g}$. The above data are also presented as percentage oil recovery, which is included in Table 3. Other works describing the drying of marjoram [7] and thyme [6] also prove that the VMD at $240 \mathrm{~W}$ is the best solution to stop volatile compounds. Vacuum-microwave drying has also proven to be the most effective method for oregano drying [9]. However, this is in contradiction with the paper by Łyczko's et al. [54] that described the drying of lavender flowers, where this method was proven to be the least effective. However, the separate systematics of hemp and lavender flowers must be taken into consideration.

In addition, the study also showed the relationship between the intensity of the treatment and the losses that occur. It was observed that with increasing intensity of drying conditions, the level of losses of volatile compounds in $\mathrm{CD}$ increased in comparison to VMD. In CD, the loss of volatile compounds was recorded from 0.16 to 0.12 (decrease by $19.01 \%$ ), with an increase in drying temperature from $50{ }^{\circ} \mathrm{C}$ to $70{ }^{\circ} \mathrm{C}$, and with an increase in power from $240 \mathrm{~W}$ to $480 \mathrm{~W}$ in VMD, the concentration decreased from 0.18 to 0.15 (decrease by $14.29 \%$ ). Sanchez et al. [8] in research on sweet basil also reported this dependence. As far as the CPD-VMFD method is concerned, the losses of volatile compounds compared to other drying methods were highest, as a $48 \%$ decrease in the volatile compounds in essential oil was observed. Consequently, this method is not a recommended drying method because it does not improve the aroma quality of dried hemp flowers. A similar situation was documented during research into drying shiitake mushrooms [55], where the combined drying method proved to be the least effective. This shows that VMD is a better method for drying cannabis flowers if the aim is to preserve as much essential oil as possible.

It is also worth noting the individual compounds of the 11 main ingredients. For example, to preserve the main fragrance compounds in the cannabis flower such as $\beta$-myrcene and $\beta$-(E)-caryophyllene, $\mathrm{CD}$ at $70{ }^{\circ} \mathrm{C}$ (for $\beta$-myrcene) and $\mathrm{CD}$ at $50{ }^{\circ} \mathrm{C}$ (for $\beta$-(E)-caryophyllene) proved to be the best drying methods.

It is also important to note the increase of $\alpha$-pinene from $2.16 \%$ to $11.13 \%$ (CPD-VMFD) and caryophyllene oxide from $3.79 \%$ to $12.16 \%$ (VMD at $480 \mathrm{~W}$ ), as well as the decrease of $\beta$-myrcene from $26.66 \%$ to $7.54 \%$ (VMD at $240 \mathrm{~W}$ ). The direction of percentage changes of individual compounds resulted from their different susceptibility to the thermal degradation as an effect to an irreversible oxidation process and volatilization enhanced by water evaporation, leading to a decrease of the dry matter content. This shows that all drying protocols had a considerable impact on the final ratio of the 
mass of individual components with different retention ability to the reduced mass of the dry matter in the hemp flower.

\subsection{Sensory Value of Cannabis sativa Flowers According to Various Drying Methods}

Only odor descriptors (perception of volatile compounds with the product outside the mouth) were evaluated, and the protocol followed was similar to that described previously to other dried herbs [7] and mushrooms [31]. Six descriptors related to fresh plant material (hemp ID: aromatics associated with fresh hemp flowers, and fresh vegetables: aromatics associated with fresh but non-identified vegetables) were assayed together with five that were mostly related to the drying process (e.g., hay-woody and burnt). The nine samples of hemp dried flowers were analyzed in three sessions in which three samples per session were randomly presented to the panel. The results presented in Table 5 clearly showed that the sample that kept most of the intensity of the fresh material was that obtained using VMD at $240 \mathrm{~W}$, followed by that prepared using the combined method at $50{ }^{\circ} \mathrm{C}$.

Table 5. Sensory profile of dried hemp flowers.

\begin{tabular}{|c|c|c|c|c|c|c|c|}
\hline \multirow{2}{*}{ Aroma Description } & \multicolumn{7}{|c|}{ Drying Method } \\
\hline & $\mathrm{CD} 50^{\circ} \mathrm{C}$ & $\mathrm{CD} 60^{\circ} \mathrm{C}$ & $\mathrm{CD} 70^{\circ} \mathrm{C}$ & VMD $240 \mathrm{~W}$ & VMD $360 \mathrm{~W}$ & VMD $480 \mathrm{~W}$ & CPD-VMFD \\
\hline Hemp ID & $3.0^{c, t}$ & $2.0^{\mathrm{c}, \mathrm{d}}$ & $1.0^{\mathrm{d}}$ & $7.0^{\mathrm{a}}$ & $2.0^{\mathrm{c}, \mathrm{d}}$ & $2.5^{\mathrm{c}, \mathrm{d}}$ & $3.0^{\mathrm{c}}$ \\
\hline Fresh vegetable & $4.5^{c}$ & $3.5^{c}$ & $1.0^{\mathrm{d}, \mathrm{e}}$ & $7.5^{\mathrm{a}}$ & $2.0^{\mathrm{d}}$ & $4.0^{c}$ & $3.5^{c}$ \\
\hline Citrus & $3.5^{b, c}$ & $2.0^{\mathrm{d}}$ & $1.0^{\mathrm{e}}$ & $5.5^{\mathrm{a}}$ & $2.0^{\mathrm{d}}$ & $3.0^{\mathrm{c}}$ & $2.5^{\mathrm{c}, \mathrm{d}}$ \\
\hline Balsamic (rosemary) & $2.5^{c}$ & $2.0^{\mathrm{c}, \mathrm{d}}$ & $1.5^{\mathrm{d}, \mathrm{e}}$ & $5.5^{\mathrm{a}}$ & $1.5^{\mathrm{d}, \mathrm{e}}$ & $2.5^{c}$ & $2.0^{c, d}$ \\
\hline Spicy (black pepper) & $2.0^{b, c}$ & $1.5^{\mathrm{c}, \mathrm{d}}$ & $1.0^{\mathrm{d}}$ & $3.5^{\mathrm{a}}$ & $1.5^{\mathrm{c}, \mathrm{d}}$ & $1.5^{\mathrm{c}}$ & $1.5^{\mathrm{c}, \mathrm{d}}$ \\
\hline Anise & $2.5^{b}$ & $2.5^{b}$ & $1.5^{\mathrm{c}}$ & $4.5^{\mathrm{a}}$ & $1.5^{c}$ & $2.0^{b, c}$ & $1.0^{\mathrm{c}, \mathrm{d}}$ \\
\hline Cooked & $0^{c}$ & $0^{c}$ & $0^{c}$ & $0^{c}$ & $0^{c}$ & $0^{c}$ & $0.5^{b}$ \\
\hline Hay-woody & $1.0^{\mathrm{c}}$ & $2.5^{b}$ & $2.5^{b}$ & $1.0^{\mathrm{c}}$ & $3.0^{\mathrm{b}}$ & $2.0^{b, c}$ & $2.0^{b, c}$ \\
\hline Camomile & $1.0^{\mathrm{c}}$ & $2.5^{\mathrm{a}, \mathrm{b}}$ & $2.5^{\mathrm{a}, \mathrm{b}}$ & $1.0^{\mathrm{c}}$ & $2.5^{\mathrm{a}, \mathrm{b}}$ & $2.0^{\mathrm{b}}$ & $2.0^{b}$ \\
\hline Earthy & 0 & 0 & 0 & 0 & 0 & 0 & 0 \\
\hline Burnt & $0^{\mathrm{b}}$ & $0^{\mathrm{b}}$ & $0^{\mathrm{b}}$ & $0^{\mathrm{b}}$ & $0^{\mathrm{b}}$ & $0^{\mathrm{b}}$ & $0^{\mathrm{b}}$ \\
\hline
\end{tabular}

${ }^{\dagger}$ Mean values followed by the same letter within the same row were not significantly different $(p>0.05)$ according to the HSD Tukey's least significance difference test.

In general, with the increasing strength of the drying process, i.e., the temperature in the $\mathrm{CD}$ and the power in the VMD, the sensory quality of the dried samples deteriorates due to significant losses of key odor compounds related to the fresh plant material. The sensory results agreed with previously discussed trends for the total content of volatile compounds.

\section{Conclusions}

The results of the study revealed that the drying kinetics of hemp flowers treated by convective drying (CD), vacuum-microwave drying (VMD), and combined drying composed of convective pre-drying followed by vacuum-microwave finish drying (CPD-VMFD) can be satisfactory described using a two-term empirical model. During the drying process, we found loses in 93 analyzed volatiles from $48 \%$ for CPD-VMFD to $15 \%$ for VMD at $240 \mathrm{~W}$, which was finally chosen as optimal for retention of aroma-active compounds. In that variant, a significant decrease of $\beta$-myrcene was observed. Taking drying time into consideration, the shortest dehydration operation was VMD at $480 \mathrm{~W}(40 \mathrm{~min})$ in contrast to $\mathrm{CD}$ at $50{ }^{\circ} \mathrm{C}(840 \mathrm{~min})$, although the loses of compounds were around $30 \%$. From a sensory point of view, the best drying treatment was VMD at $240 \mathrm{~W}$, because it produced dried samples most resembling the fresh material, with high intensities of key sensory descriptors such as hemp flower ID, fresh vegetables, citrus, balsamic, and anise. Unfortunately, that process produced the most changes in flower color. Although combined drying (CPD-VMFD) could be advantageous from a practical point of view, too much degradation of the chemical composition identified in the raw material prevents this method to be applied to a greater extent. Taking into account the influence of individual drying conditions on the drying time and quality parameters of the dried product, VMD at $240 \mathrm{~W}$ can be recommended by the industry as the best option for hemp flower drying. 
Supplementary Materials: The following are available online at http://www.mdpi.com/2304-8158/9/8/1118/s1, the Supplementary Materials contain chromatograms from the GC-MS analysis of volatile compounds content of hemp flowers, Figure S1: Fresh hemp flower-GC-MS volatile profile analysis; Figure S2: Dried hemp flower at 240W-GC-MS volatile profile analysis.

Author Contributions: Conceptualization, A.K., N.P., and A.S.; methodology, A.K., N.P., K.M., A.F., A.S., and A.A.C.-B.; validation, A.K., N.P., K.M., A.F., A.Z., R.K., K.W., A.S., H.R., and A.A.C.-B.; formal analysis, A.K., N.P., K.M., A.F., A.Z., R.K., K.W., A.S., and A.A.C.-B.; investigation, A.K., N.P., K.M., A.Z., K.W., and A.A.C.-B.; resources, A.K., A.S., and A.A.C.-B.; data curation, A.K., N.P., and K.M.; writing-original draft preparation, A.K. and N.P.; writing-review and editing, A.K., N.P., and K.M.; visualization, A.K., N.P., K.M., and A.A.C.-B.; supervision, A.S., A.F., R.K. H.R., and Á.A.C.-B.; project administration, A.K.; funding acquisition, A.K. All authors have read and agreed to the published version of the manuscript.

Funding: This research received no external funding.

Conflicts of Interest: The authors declare no conflict of interest.

\section{References}

1. Bonini, S.A.; Premoli, M.; Tambaro, S.; Kumar, A.; Maccarinelli, G.; Memo, M.; Mastinu, A. Cannabis sativa: A comprehensive ethnopharmacological review of a medicinal plant with a long history. J. Ethnopharmacol. 2018, 227, 300-315. [CrossRef] [PubMed]

2. Russo, E.B.; Jiang, H.; Li, X.; Sutton, A.; Carboni, A.; del Bianco, F.; Mandolino, G.; Potter, D.J.; Zhao, Y.; Bera, S.; et al. Phytochemical and genetic analyses of ancient cannabis from Central Asia. J. Exp. Bot. 2008, 59, 4171-4182. [CrossRef] [PubMed]

3. Upton, R.; ElSohly, M.; Pharmacopoeia, A.H. Cannabis Inflorescence: Cannabis Spp.; Standards of Identity, Analysis, and Quality Control; American Herbal Pharmacopoeia: Scotts Valley, CA, USA, 2014.

4. Taura, F.; Sirikantaramas, S.; Shoyama, Y.; Yukihiro, S.; Morimoto, S. Phytocannabinoids in Cannabis sativa: Recent studies on biosynthetic enzymes. Chem. Biodivers. 2007, 4, 1649-1663. [CrossRef]

5. Chua, L.Y.W.; Chong, C.H.; Chua, B.L.; Figiel, A. Influence of drying methods on the antibacterial, antioxidant and essential oil volatile composition of herbs: A review. Food Bioprocess Technol. 2019, 12, 450-476. [CrossRef]

6. Calín-Sánchez, Á.; Figiel, A.; Lech, K.; Szumny, A.; Carbonell-Barrachina, Á.A. Effects of drying methods on the composition of thyme (Thymus vulgaris L.) essential oil. Dry. Technol. 2013, 31, 224-235. [CrossRef]

7. Calín-Sánchez, Á.; Figiel, A.; Lech, K.; Szumny, A.; Martinez-Tomé, J.; Carbonell-Barrachina, Á.A. Drying methods affect the aroma of Origanum majorana L. analyzed by GC-MS and descriptive sensory analysis. Ind. Crop. Prod. 2015, 74, 218-227. [CrossRef]

8. Calín-Sánchez, Á.; Lech, K.; Szumny, A.; Figiel, A.; Carbonell-Barrachina, Á.A. Volatile composition of sweet basil essential oil (Ocimum basilicum L.) as affected by drying method. Food Res. Int. 2012, 48, $217-225$. [CrossRef]

9. Figiel, A.; Szumny, A.; Gutiérrez-Ortízac, A.; Carbonell-Barrachina, Á.A. Composition of oregano essential oil (Origanum vulgare) as affected by drying method. J. Food Eng. 2010, 98, 240-270. [CrossRef]

10. Xing, Y.; Lei, H.; Wang, J.; Wang, Y.; Wang, J.; Xu, H. Effects of different drying methods on the total phenolic, rosmarinic acid and essential oil of purple perilla leaves. J. Essent. Oil Bear. Plants 2017, 20, 1594-1606. [CrossRef]

11. Figiel, A.; Michalska, A. Overall quality of fruits and vegetables products affected by the drying processes with the assistance of vacuum-microwaves. Int. J. Mol. Sci. 2017, 18, 71. [CrossRef]

12. Chua, K.J.; Chou, S.K. Chapter 24: Recent advances in hybrid drying technologies. In Emerging Technologies for Food Processing, 2nd ed.; Academic Press: Cambridge, MA, USA, 2014.

13. Calzolari, D.; Magagnini, G.; Lucini, L.; Grassi, G.; Appendino, G.B.; Amaducci, S. High added-value compounds from Cannabis threshing residues. Ind. Crop. Prod. 2017, 108, 558-563. [CrossRef]

14. Tang, K.; Struik, P.C.; Yin, X.; Calzolari, D.; Musio, S.; Thouminot, C.; Bjelková, M.; Stramkale, V.; Magagnini, G.; Amaducci, S. A comprehensive study of planting density and nitrogen fertilization e_ect on dual-purpose hemp (Cannabis sativa L.) cultivation. Ind. Crop. Prod. 2017, 107, 427-438. [CrossRef]

15. Welling, M.T.; Liu, L.; Shapter, T.; Raymond, C.A.; King, G.J. Characterisation of cannabinoid composition in a diverse Cannabis sativa L. germplasm collection. Euphytica 2017, 208, 463-475. [CrossRef]

16. Meier, C.; Mediavilla, V. Factors influencing the yield and the quality of hemp (Cannabis sativa L.) essential oil. J. Int. Hemp Assoc. 1998, 5, 16-20. 
17. Nissen, L.; Zatta, A.; Stefanini, I.; Grandi, S.; Sgorbati, B.; Biavati, B.; Monti, A. Characterization and antimicrobial activity of essential oils of industrial hemp varieties (Cannabis sativa L.). Fitoterapia 2010, 81, 413-419. [CrossRef]

18. Bedini, S.; Flamini, G.; Cosci, F.; Ascrizzi, R.; Benelli, G.; Conti, B. Cannabis sativa and Humulus lupulus essential oils as novel control tools against the invasive mosquito Aedes albopictus and fresh water snail Physella acuta. Ind. Crop. Prod. 2016, 85, 318-323. [CrossRef]

19. Górski, R.; Sobieralski, K.; Siwulski, M. The effect of hemp essential oil on mortality Aulacorthum Solani Kalt. And Tetranychus Urticae Koch. Ecol. Chem. Eng. 2016, 23, 505-511. [CrossRef]

20. Wielgusz, K.; Heller, K.; Byczyńska, M. The assessment of fungistatic effect of hemp essential oil as seed dressing, depending on the composition. J. Res. Appl. Agric. Eng. 2012, 57, 183-187.

21. Synowiec, A.; Rys, M.; Bocianowski, J.; Wielgusz, K.; Byczyńska, M.; Heller, K.; Kalemba, D. Phytotoxic effect of fiber hemp essential oil on germination of some weeds and crops. J. Essent. Oil Bear. Plants 2016, 19, 262-276. [CrossRef]

22. Mastinu, A.; Premoli, M.; Ferrari-Toninelli, G.; Tambaro, S.; Maccarinelli, G.; Memo, M.; Bonini, S.A. Cannabinoids in health and disease: Pharmacological potential in metabolic syndrome and neuroinflammation. Horm. Mol. Biol. Clin. Investig. 2018, 227, 300-315. [CrossRef]

23. Lim, K.; See, Y.M.; Lee, J. A systematic review of the effectiveness of medical cannabis for psychiatric, movement and neurodegenerative disorders. Clin. Psychopharmacol. Neurosci. 2017, 15, 301-312. [CrossRef]

24. Callaway, J.C. Hempseed as a nutritional resource: An overview. Euphytica 2004, 140, 65-72. [CrossRef]

25. Leizer, C.; Ribnicky, D.; Poulev, A.; Dushenkov, S.; Raskin, I. The composition of hemp seed oil and its potential as an important source of nutrition. J. Nutraceuticals Funct. Med. Foods 2000, 2, 35-53. [CrossRef]

26. Calín-Sánchez, Á.; Figiel, A.; Wojdyło, A.; Szarycz, M.; Carbonell-Barrachina, Á.A. Drying of garlic slices using convective pre-drying and vacuum-microwave finishing drying: Kinetics, energy consumption, and quality studies. Food Bioprocess Technol. 2014, 7, 398-408. [CrossRef]

27. The NIST Mass Spectral Search Program for the NIST/EPA/NIH EI and NIST Tandem Spectral Library; Standard Reference Data Program of the National Institute of Standards and Technology: Gaithersburg, MD, USA, 2017.

28. Mondello, L. Mass Spectra of Flavors and Fragrances of Natural and Synthetic Compounds, 3rd ed.; Wiley: Hoboken, NJ, USA, 2015.

29. Lucero, M.; Estell, R.; Tellez, M.; Fredrickson, E. A retention index calculator simplifies identification of plant volatile organic compounds. Phytochem. Anal. 2009, 20, 378-384. [CrossRef]

30. Adams, R.P. Identification of Essential Oil Components by Gas Chromatography/Mass Spectrometry, 4th ed.; Allured Pub Corp: Carol Stream, IL, USA, 2017.

31. Politowicz, J.; Lech, K.; Sánchez-Rodríguez, L.; Figiel, A.; Szumny, A.; Grubor, M.; Carbonell-Barrachina, Á.A. Volatile composition and sensory profile of oyster mushroom as affected by drying method. Dry. Technol. 2018, 36, 685-696. [CrossRef]

32. Calín-Sanchez, Á.; Figiel, A.; Szarycz, M.; Lech, K.; Nuncio-Jáuregui, N.; Carbonell-Barrachina, Á.A. Drying kinetics and energy consumption in the dehydration of pomegranate (Punica Granatum L.) arils and rind. Food Bioprocess Technol. 2014, 7, 2071-2083. [CrossRef]

33. Thorat, I.D.; Mohapatra, D.; Sutar, R.F.; Kapdi, S.S.; Jagtap, D.D. mathematical modeling and experimental study on thin-layer vacuum drying of ginger (Zingiber Officinale R.) slices. Food Bioprocess Technol. 2012, 5, 1379-1383. [CrossRef]

34. Sitkei, G. Developments in Agricultural Engineering 8. Mechanics of Agricultural Materials; Akadémiai Kiadó: Budapest, Hungary; Elsevier Science Publishers: Amsterdam, The Netherlands, 1986.

35. Rafiee, S.; Sharifi, M.; Keyhani, A.; Omid, M.; Jafari, A.; Mohtasebi, S.S.; Mobli, H. Modeling effective moisture diffusivity of orange slice (Thompson Cv.). Int. J. Food Prop. 2010, 13, 32-40. [CrossRef]

36. Akpinar, E.K.; Bicer, Y.; Yildiz, C. Thin layer drying of red pepper. J. Food Eng. 2003, 59, 99-104. [CrossRef]

37. Lech, K.; Figiel, A.; Wojdyło, A.; Korzeniowska, M.; Serowik, M.; Szarycz, M. Drying kinetics and bioactivity of beetroot slices pretreated in concentrated chokeberry juice and dried with vacuum microwaves. Dry. Technol. 2015, 33, 1644-1653. [CrossRef]

38. Łyczko, J.; Jałoszyński, K.; Surma, M.; Masztalerz, K.; Szumny, A. HS-SPME analysis of true lavender (Lavandula Angustifolia Mill.) leaves treated by various drying methods. Molecules 2019, 24, 764. [CrossRef]

39. Doymaz, İ. Drying kinetics, rehydration and colour characteristics of convective hot-air drying of carrot slices. Heat Mass Transf. 2017, 53, 25-35. [CrossRef] 
40. Ozgen, F. Experimental investigation of drying characteristics of cornelian cherry fruits (Cornus Mas L.). Heat Mass Transf. 2015, 51, 343-352. [CrossRef]

41. Chua, L.Y.W.; Chua, B.L.; Figiel, A.; Chong, C.H.; Wojdyło, A.; Szumny, A.; Lech, K. Characterisation of the convective hot-air drying and vacuum microwave drying of Cassia Alata: Antioxidant activity, essential oil volatile composition and quality studies. Molecules 2019, 24, 1625. [CrossRef] [PubMed]

42. Nowicka, P.; Wojdyło, A.; Lech, K.; Figiel, A. Chemical composition, antioxidant capacity, and sensory quality of dried sour cherry fruits pre-dehydrated in fruit concentrates. Food Bioprocess Technol. 2015, 8, 2076-2095. [CrossRef]

43. Taskin, O.; Polat, A.; Izli, N.; Asik, B.B. Intermittent microwave-vacuum drying effects on pears. Pol. J. Food Nutr. Sci. 2019, 69, 101-108. [CrossRef]

44. Szychowski, P.J.; Lech, K.; Sendra-Nadal, E.; Hernández, F.; Figiel, A.; Wojdyło, A.; Carbonell-Barrachina, Á.A. Kinetics, biocompounds, antioxidant activity, and sensory attributes of quinces as affected by drying method. Food Chem. 2018, 255, 157-164. [CrossRef]

45. Figiel, A. Drying kinetics and quality of beetroots dehydrated by combination of convective and vacuum-microwave methods. J. Food Eng. 2010, 98, 461-470. [CrossRef]

46. Šumić, Z.; Tepić, A.; Vidović, S.; Jokić, S.; Malbaša, R. Optimization of frozen sour cherries vacuum drying process. Food Chem. 2013, 136, 55-63. [CrossRef]

47. Benelli, G.; Pavela, R.; Petrelli, R.; Cappellacci, L.; Santini, G.; Fiorini, D.; Sut, S.; Dall'Acqua, S.; Canale, A.; Maggi, F. The essential oil from industrial hemp (Cannabis sativa L.) by-products as an effective tool for insect pest management in organic crops. Ind. Crop. Prod. 2018, 122, 308-315. [CrossRef]

48. Benelli, G.; Pavela, R.; Lupidi, G.; Nabissi, M.; Landry Stephane, N.; Cappellacci, L.; Fiorini, D.; Sut, S.; Dall'Acqua, S.; Maggi, F. The crop-residue of fiber hemp cv. Futura 75: From a waste product to a source of botanical insecticides. Environ. Sci. Pollut. Res. 2017, 25, 10515-10525. [CrossRef]

49. Mediavilla, V.; Steinemann, S. Essential oil of Cannabis sativa L. strains. J. Int. Hemp Assoc. 1997, 4, 80-82.

50. Iseppi, R.; Brighenti, V.; Licata, M.; Lambertini, A.; Sabia, C.; Messi, P.; Pellati, F.; Benvenuti, S. Antibacterial activity of essential oils from fibre-type Cannabis sativa L. (Hemp). Molecules 2019, 24, 2302. [CrossRef]

51. Vuerich, M.; Ferfuia, C.; Zuliani, F.; Piani, B.; Sepulcri, A.; Mario Baldini, M. Yield and quality of essential oils in hemp varieties in different environments. Agronomy 2019, 9, 356. [CrossRef]

52. Liang, Q.; Liang, Z.; Wang, J.; Xu, W. Essential oil composition of Salvia miltiorrhiza flower. Food Chem. 2009, 113, 592-594. [CrossRef]

53. Chalchat, J.; Ozcan, M.M. Comparative essential oil composition of flowers, leaves and stems of basil (Ocimum basilicum L.) used as herb. Food Chem. 2008, 110, 501-503. [CrossRef]

54. Łyczko, J.; Jałoszyński, K.; Surma, M.; García-Garví, J.M.; Carbonell-Barrachina, Á.A.; Szumny, A. Determination of various drying methods' impact on odour quality of true lavender (Lavandula angustifolia Mill.) flowers. Molecules 2019, 24, 2900. [CrossRef]

55. Politowicz, J.; Lech, K.; Lipan, L.; Figiel, A.; Carbonell-Barrachina, Á.A. Volatile composition and sensory profile of shiitake mushrooms as affected by drying method. J. Sci. Food Agric. 2017, 98, 1511-1521. [CrossRef]

(C) 2020 by the authors. Licensee MDPI, Basel, Switzerland. This article is an open access article distributed under the terms and conditions of the Creative Commons Attribution (CC BY) license (http://creativecommons.org/licenses/by/4.0/). 